\title{
Evaluation of (PARP-1) Expression in Gastric Carcinoma by Immunohistochemistry and Quantitative Real-Time PCR and its Relation to HER2 Status
}

\author{
MARWA S. ABD ALLAH, M.D.*; HEBA M. ABD EL KARIEM, M.D.** and HEBA M. RASHAD, M.D.* \\ The Departments of Pathology* and Biochemistry**, Faculty of Medicine, Benha University, Egypt
}

\begin{abstract}
Background: PARP-1 overexpression has been identified in several malignancies. Few studies have handled the expression of PARP-1 protein in gastric carcinoma and its associations with outcome.

Aim of Study: This study aimed at exploring the significance of PARP-1 expression in gastric adenocarcinoma and
\end{abstract} correlation with HER2 status.

Subjects and Methods: Quantitative expression of PARP1 proteins was assayed by Immunohistochemistry in 40 cases of gastric adenocarcinoma. PARP-1 mRNA was moreover evaluated by Quantitative Real-Time Polymerase Chain Reaction.

Results: The level of expression of mRNA expression level was significantly increased in 25 of $40(62.5 \%)$ of gastric adenocarcinoma tissues compared with the corresponding adjacent non cancer tissues $(p<0.001)$. Positive expression of PARP-1 protein was detected in $23 / 40(57.5 \%)$ of gastric adenocarcinoma. PARP-1 expression in cancer tissues was significantly higher than adjacent non-cancerous tissue $(p<0.001)$. The aberrant high expression of PARP-1 showed significant correlation with depth of invasion $(p<0.001)$ advanced stage $(p<0.001)$, nodal $(p<0.05)$ and distant metastasis $(p<0.001)$. Positive correlation was detected between PARP-1 and positive HER2 status $(p<0.001)$.

Conclusion: PARP-1 level is up regulated significantly in gastric adenocarcinoma tissue. PARP-1 is positively correlated with positive HER2 status and poor prognostic factors. PARP-1 might be potential prognostic marker for gastric adenocarcinoma.

Key Words: PARP-1 - HER2 - Gastric carcinoma - Immunohistochemistry - Quantitative real-time PCR.

Correspondence to: Dr. Marwa S. Abd Allah, The Department of Pathology, Faculty of Medicine, Benha University, Egypt

\section{Introduction}

GASTRIC Carcinoma (GC) is ranking as the fourth most common malignancy and the third leading cause of cancer related mortality worldwide [1] Most of gastric carcinomas are frequently discovered in an advanced stage [2]. Hence, it is necessary to identify novel biomarkers for early detection of gastric carcinoma.

Poly (ADP-ribose) polymerases (PARPs) are multitasking protein translation enzymes. PARPs are believed to be activated by damaging DNA fragments. The PARP family includes multiple members, PARP1/4, PARP5 $\mathrm{a}$ and PARP5 0 plus PARP6 [3].

PARP1 is ranking the most abundant member of the PARP family and is considered a key DNA repair factor involved in base excision repair occurring in response to DNA damage [4]. Beside the well-known function of PARP 1 in DNA damage repair, all recent studies have revealed that PARP1 play much wider role in malignancy as transcriptional regulation, chromatin remodeling and miRNA processing [5].

PARP1 expression has been detected to be increased significantly in a variety of cancers, including uterine, breast, ovarian, lung, and skin cancers [6]. PARP1 was believed to act as an oncogenic gene in breast cancer [7] and prostate cancer [8]. PARP1 protein expression was elevated in HER2+ breast tumors and correlation between PARP 1 and HER2 in breast cancer was documented in various studies [9].

This made us curious to investigate the relation between PARP1 expression and HER2, status in 
gastric adenocarcinoma. Moreover, the present study aimed for assessment of PARP1 expression in gastric carcinoma and adjacent non-cancerous tissue by Quantitative Real-Time PCR and Immunohistochemistry and to correlate it with different clinicopathological factors.

\section{Subjects and Methods}

Subjects:

This is a retrospective controlled study carried upon 40 specimens of formalin-fixed, paraffinembedded gastric adenocarcinoma. They were collected from Archives of Pathology Department, Benha Faculty of Medicine during the years 20132018. In each case, clinicopathologic findings, including age, gender, lymph node and distant metastasis status, were obtained from pathology reports and hospital records after approval by the Ethical Committee at Benha Faculty of Medicine. The study cases were previously stained immunohistochemically by HER2 and the HER2 status was revised.
Quantitative real-time $R T$-reassessment of PARPI MRNA:

Total RNA was extracted from cancerous and adjacent non-cancer gastric tissues using the $\mathrm{RNe}$ asy extraction kit (Qiagen-USA) according to the manufacturer's protocol. The RNA concentration was measured using nanodrops pectrophotometer (Biowave II Germany). Then RNA was reverse transcribed into cDNA using the iScriptcDNA Synthesis Kit (Bio-Rad, USA). Quantitative PCR was applied using the Ready Mix PCR Reaction Mix kit (iScriptTM One-Step RT-PCR Kit with SYBR ${ }^{\circledR}$ Green (Bio-Rad, USA). PCR thermal cycling conditions were: $10 \mathrm{~min}$ at $50^{\circ} \mathrm{C}, 5 \mathrm{~min}$ at $95^{\circ} \mathrm{C}$ then 40 cycles $\left(10 \mathrm{sec}\right.$ at $95^{\circ} \mathrm{C} 30 \mathrm{sec}$ at $55^{\circ} \mathrm{C}$, $1 \mathrm{~min}$ at $55^{\circ} \mathrm{C}$ ) using Rotorgene real time PCR system and the related software for analysis and interpretation (Qiagen-S. Korea). P-actin used as the reference gene for internal control. The PCR primers sequences are shown in (Table 1), data were analyzed using the comparative $\mathrm{Ct}(2-\mathrm{AACT})$ method.

Table (1): The PCR primers sequences.

\begin{tabular}{lll}
\hline Gene & Forward primer & Reverse primer \\
\hline PARP 1 & 5' TGCAGCTAGGGATGTGAATCTTC-3' & 5' GGAGCCCAGTCCATCAGAACT-3' \\
P-actin & 5' GTGACATCCACACCCAGAGG-3' & 5' ACAGGATGTCAAAACTGCCC-3' \\
\hline
\end{tabular}

\section{Histopathological study:}

Conventional hematoxylin and eosin $(\mathrm{H} \& \mathrm{E})$ stain was performed for all cases. Each case was examined by two specialists for (1) confirmation of the previous diagnosis, (2) assessment of tumor grade according to the WHO (2010), (3) assessment of Pathological T stage (depth of invasion) (4), assessment of other histopathological features as lymph node and distant metastasis. Stage was defined according to AJCC on Cancer Criteria (2017)

\section{Immunohistochemical study:}

Sections were prepared and immunostained for PARP1 Rabbit polyoclonal antibody (clone- ab 194586) (cat. ab6079; Abcam, Cambridge, UK) at a dilution of 1:100.DAP was utilized as a chromogen. IHC staining was performed, using detection kit (Thermoscientific, USA) according to the manufacturer's data. Positive control for PARP1 was human placental tissue. For negative controls, the primary antibody was replaced with phosphatebuffered saline.

\section{Immunohistochemical assessment:}

PARP1: Expression was detected mainly in the nucleus of positively stained cells. The intensity of staining was classified to four groups: 0 indicate no staining; 1 indicate weak staining; 2 indicate moderate staining and 3 indicate strong staining. The percentage was scored as follow: 0 if $<5 \%, 1$ if $(5 \%-25 \%) ; 2$ if $(25 \%-50 \%) .3$ if $(51 \%-75 \%) .4$ if $>75 \%$. After multiplication the percentage by intensity of stained cells, score of 0-4 was considered negative immunoreactivity, while score greater than 4 was considered positive immunoreactivity [10].

HER2: HER2 scoring was divided into 4 groups, dependent on the extension and intensity: 0 , with no positivity or positivity in the cell membrane in $<10 \%$ of the cells; $1+$, weak or hardly perceptible stain in $>10 \%$ of the cells; $2+$, weak to moderate, complete or in the basolateral membrane in $>10 \%$ of the cells; $3+$ complete, intense, positive or in the basolateral membrane in $>10 \%$ of the cells. Only the cases of the $3+$ group were considered positive for HER 2 overexpression [11]

\section{Statistical analysis:}

Analysis of the collected data was performed by SPSS version 16 software (Spss Inc, Chicago, ILL Company). Chi square ( $\mathrm{X}^{2}$ ) or Fisher's Exact Test (FET) were applied during the analysis of 
categorical data. Differences between 2 groups were tested using student " $t$ " test. Correlations among non-parametric variables were evaluated by Spearman's correlation coefficient (rho). The accepted level of significance in this work was stated at 0.05 ( $p<0.05$ was considered significant).

\section{Results}

\section{Patient clinicopathologic data:}

The present retrospective study included 40 cases of gastric adenocarcinoma. The clinicopathological data were summarized in (Table 2).

Table (2): Clinicopathologic data of study cases.

\begin{tabular}{|c|c|c|}
\hline Study groups & Number & Percent \\
\hline \multicolumn{3}{|l|}{ Sex: } \\
\hline Female & 16 & 40 \\
\hline Male & 24 & 60 \\
\hline \multicolumn{3}{|l|}{ Type: } \\
\hline Tubular Adenorcarinom & 22 & 55 \\
\hline Mucinous carcinoma & 6 & 15 \\
\hline Signet ring carcinoma & 12 & 30 \\
\hline \multicolumn{3}{|l|}{ Grade: } \\
\hline Grade II & 17 & 42.5 \\
\hline Grade III & 23 & 57.5 \\
\hline \multicolumn{3}{|l|}{ Depth of invasion: } \\
\hline $\mathrm{T} 2$ & 5 & 12.5 \\
\hline T3 & 14 & 35 \\
\hline $\mathrm{T} 4$ & 21 & 52.5 \\
\hline \multicolumn{3}{|l|}{ LN metastasis: } \\
\hline Absent & 7 & 17.5 \\
\hline Present & 33 & 82.5 \\
\hline \multicolumn{3}{|l|}{ Distant metastasis: } \\
\hline Absent & 25 & 62.5 \\
\hline Present & 15 & 37.5 \\
\hline \multicolumn{3}{|l|}{ TNM stage: } \\
\hline Stage II & 8 & 20 \\
\hline Stage III & 17 & 42.5 \\
\hline Stage IV & 15 & 37.5 \\
\hline \multicolumn{3}{|l|}{ Tumor size: } \\
\hline$<5 \mathrm{~cm}$ & 30 & 75 \\
\hline$>5 \mathrm{~cm}$ & 10 & 25 \\
\hline Total & 40 & 100 \\
\hline
\end{tabular}

$q R T-P C R$ results:

The mRNA level of PARP 1 was measured by qRT-PCR in 40 gastric adenocarcinoma tissue and adjacent non cancer tissues. The level of expression of mRNA expression level was significantly increased in 25 of $40(62.5 \%)$ of gastric adenocarcinoma tissues compared with the corresponding adjacent non cancer tissues $(p<0.001)$, as shown in Fig. (1).

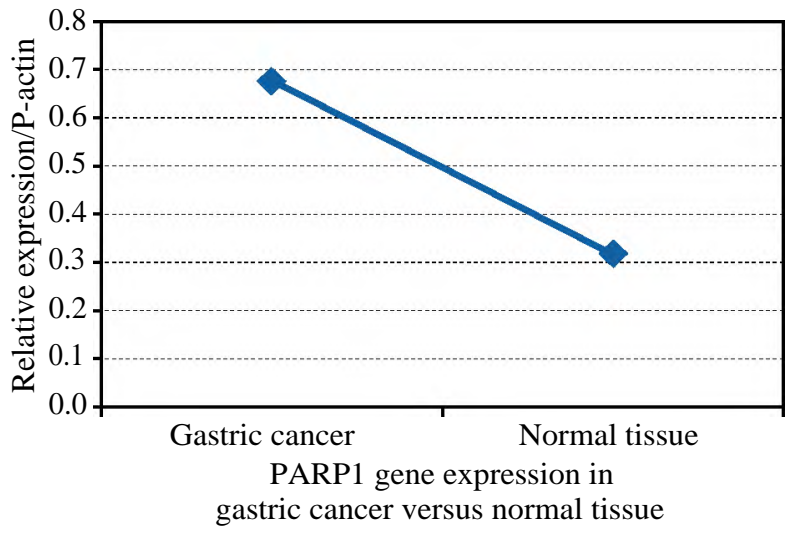

Fig. (1): PARP1 Gene expression in gastric adenocarcinoma tissue versus non-cancerous tissues by RT-PCR (PARP1/p actin, $\mathrm{n}=40, p<0.001$ ).

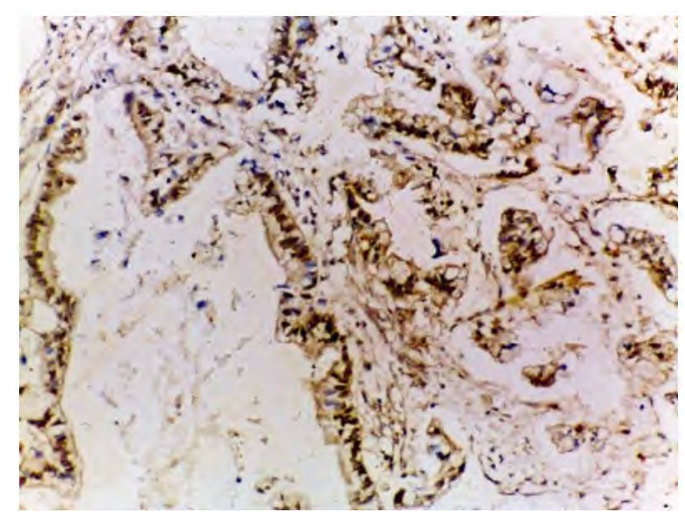

Fig. (2): Nuclear expression of PARP1 score (8) in gastric mucinous adenocarcinoma (IHC, X200).

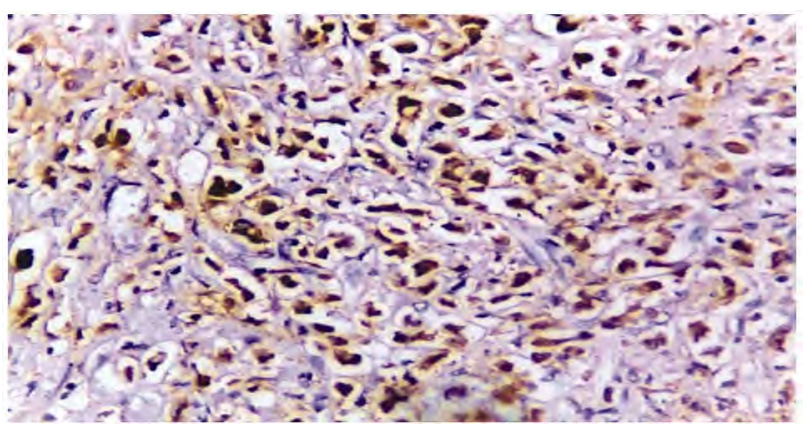

Fig. (3): Strong nuclear expression of PARP1, score (9) in signet ring gastric carcinoma (IHC X400).

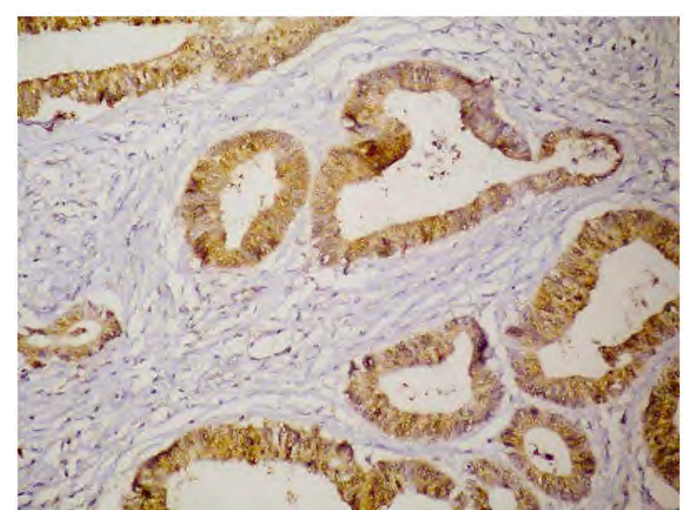

Fig. (4): Strong membranous expression of HER2, score (3) in gastric tubular adenocarcinoma (IHC, X200). 
Table (3): PARP1 immunostaining in gastric adenocarcinoma cases.

\begin{tabular}{|c|c|c|c|c|c|c|c|c|c|c|}
\hline Variable & & $\begin{array}{l}\text { ent non- } \\
\text { pus tissue }\end{array}$ & Can & us tissue & $\begin{array}{c}\text { Test of } \\
\text { significance }\end{array}$ & $p$ & $\begin{array}{c}\text { Cut out } \\
\text { point }\end{array}$ & $\begin{array}{c}\text { Sensitivity } \\
\%\end{array}$ & $\begin{array}{c}\text { Specificity } \\
\%\end{array}$ & AUC \\
\hline \multicolumn{11}{|l|}{ PARP1: } \\
\hline Negative & 40 & $100.0 \%$ & 17 & $42.5 \%$ & $\chi^{2}=25.7$ & $<0.001$ & $>2$ & $80.5 \%$ & $85.4 \%$ & 0.896 \\
\hline Positive & 0 & $0.0 \%$ & 23 & $57.5 \%$ & & $(\mathrm{HS})^{*}$ & & & & \\
\hline
\end{tabular}

*(HS): Highly Significant.

Table (4): Correlation of PARP1 with clinicopathological variables.

\begin{tabular}{|c|c|c|c|c|c|c|c|}
\hline \multirow{3}{*}{ Variable } & \multirow{3}{*}{$\mathrm{N}$} & \multicolumn{4}{|c|}{ PARP 1} & \multirow{3}{*}{ Test of sig. } & \multirow{3}{*}{$p$} \\
\hline & & \multicolumn{2}{|c|}{$\begin{array}{l}\text { Negative } \\
(\mathrm{n}=17)\end{array}$} & \multicolumn{2}{|c|}{$\begin{array}{l}\text { Positive } \\
(\mathrm{n}=23)\end{array}$} & & \\
\hline & & No. & $\%$ & No. & $\%$ & & \\
\hline Age $(y s):($ Mean $\pm \mathrm{SD})$ & 40 & 13.5 & \pm 51.5 & 12. & \pm 54.9 & $\mathrm{ZMWU}=0.62$ & $0.53(\mathrm{NS})$ \\
\hline $\begin{array}{l}\text { Sex: } \\
\text { Female } \\
\text { Male }\end{array}$ & $\begin{array}{l}15 \\
25\end{array}$ & $\begin{array}{l}7 \\
10\end{array}$ & $\begin{array}{l}41.2 \\
58.8\end{array}$ & $\begin{array}{l}8 \\
15\end{array}$ & $\begin{array}{l}37.5 \\
62.5\end{array}$ & $\chi^{2}=0.06$ & $0.81(\mathrm{NS})$ \\
\hline $\begin{array}{l}\text { Type: } \\
\text { Adenocarcinoma } \\
\text { Mucoid carcinoma } \\
\text { Signet ring carcinoma }\end{array}$ & $\begin{array}{l}22 \\
6 \\
12\end{array}$ & $\begin{array}{l}8 \\
2 \\
7\end{array}$ & $\begin{array}{l}47.1 \\
11.8 \\
41.2\end{array}$ & $\begin{array}{l}14 \\
4 \\
5\end{array}$ & $\begin{array}{l}62.5 \\
16.7 \\
20.8\end{array}$ & $\mathrm{FET}=1.97$ & $0.38(\mathrm{NS})$ \\
\hline $\begin{array}{l}\text { Grade: } \\
\text { Grade II } \\
\text { Grade III }\end{array}$ & $\begin{array}{l}18 \\
22\end{array}$ & $\begin{array}{l}8 \\
9\end{array}$ & $\begin{array}{l}41.2 \\
58.8\end{array}$ & $\begin{array}{l}10 \\
13\end{array}$ & $\begin{array}{l}45.8 \\
54.2\end{array}$ & $\chi^{2}=0.09$ & $0.76(\mathrm{NS})$ \\
\hline $\begin{array}{l}\text { Depth of invasion: } \\
\text { T2 } \\
\text { T3 } \\
\text { T4 }\end{array}$ & $\begin{array}{l}5 \\
15 \\
20\end{array}$ & $\begin{array}{l}4 \\
9 \\
4\end{array}$ & $\begin{array}{l}23.5 \\
52.9 \\
23.5\end{array}$ & $\begin{array}{l}1 \\
6 \\
16\end{array}$ & $\begin{array}{l}4.2 \\
25.0 \\
70.8\end{array}$ & $\mathrm{FET}=19.3$ & $<0.001(\mathrm{HS})^{* *}$ \\
\hline $\begin{array}{l}\text { LN metastasis: } \\
\text { Absent } \\
\text { Present }\end{array}$ & $\begin{array}{l}10 \\
30\end{array}$ & $\begin{array}{l}7 \\
10\end{array}$ & $\begin{array}{l}35.3 \\
64.7\end{array}$ & $\begin{array}{l}3 \\
20\end{array}$ & $\begin{array}{l}4.2 \\
95.8\end{array}$ & $\mathrm{FET}=8.28$ & $<0.05(\mathrm{~S})^{*}$ \\
\hline $\begin{array}{l}\text { Distant metastasis: } \\
\text { Absent } \\
\text { Present }\end{array}$ & $\begin{array}{l}25 \\
15\end{array}$ & $\begin{array}{l}17 \\
0\end{array}$ & $\begin{array}{l}100.0 \\
0.0\end{array}$ & $\begin{array}{l}8 \\
15\end{array}$ & $\begin{array}{l}33.3 \\
66.7\end{array}$ & $\chi^{2}=28.5$ & $<0.001(\mathrm{HS})^{* *}$ \\
\hline $\begin{array}{l}\text { TNM: } \\
\text { Stage II } \\
\text { Stage III } \\
\text { Stage IV }\end{array}$ & $\begin{array}{l}8 \\
17 \\
15\end{array}$ & $\begin{array}{l}8 \\
9 \\
0\end{array}$ & $\begin{array}{l}47.1 \\
52.9 \\
0.0\end{array}$ & $\begin{array}{l}0 \\
8 \\
15\end{array}$ & $\begin{array}{l}0.0 \\
33.3 \\
66.7\end{array}$ & $\mathrm{FET}=26.5$ & $<0.001(\mathrm{HS})^{* *}$ \\
\hline $\begin{array}{l}\text { Size: } \\
\quad \leq 5 \mathrm{~cm} \\
\quad>5 \mathrm{~cm}\end{array}$ & $\begin{array}{c}21 \\
19\end{array}$ & $\begin{array}{l}11 \\
6\end{array}$ & $\begin{array}{l}100.0 \\
0.0\end{array}$ & $\begin{array}{l}10 \\
13\end{array}$ & $\begin{array}{l}58.3 \\
41.7\end{array}$ & FET & $0.78(\mathrm{NS})$ \\
\hline
\end{tabular}

(NS): Non Significant.

$\left(\mathrm{S}^{*}\right)$ : Significant.

(HS**): Highly Significant.

Immunohistochemical results:

PARP1 immunostaining in studied cases:

Comparing the levels of PARP1 in gastric adenocarcinoma tissues and adjacent non-cancerous tissues revealed significant higher expression in the cancerous group $(p<0.001)$. Concerning predictively of the PARP1 in early diagnosis of cancerous group, sensitivity was $(80.5 \%)$ and specificity was $(85.4 \%)$ as shown in (Table 3 ).

Correlation of PARP1 with clinicopathological variables: PARP1 was significantly correlated with depth of invasion $(p<0.001)$, advanced tumor stage $(p<0.001)$, nodal $(p<0.05)$ and distant metastasis status $(p<0.001)$. Other histopathological factors failed to obtain statistical significant differences as detailed in (Table 4).

Correlation between PARP1 and HER2 in the studied cases: The present study demonstrated a high significant positive correlation between PARP1 and HER2. Out of 23 cases positive for PARP1, 13 cases $(56.5 \%)$ were positive for HER 2 while 10 cases $(43.5 \%)$ were negative $(p<0.001)$ as detailed in (Table 5). 
Table (5): Correlation between PARP1 and HER2.

\begin{tabular}{lllll}
\hline \multirow{2}{*}{ Markers } & \multicolumn{2}{c}{ PARP 1 } & & $\begin{array}{c}p \text { - } \\
\text { value }\end{array}$ \\
\cline { 2 - 3 } & Negative (17) & Positive (23) & & \\
\hline HER2: & & & & \\
Negative (26) & $16(94.1 \%)$ & $10(43.5 \%)$ & 0.685 & $<0.001$ \\
Positive (14) & $1(5.9 \%)$ & $13(56.5 \%)$ & & $(\mathrm{HS})^{*}$ \\
\hline *(HS): Highly Significan
\end{tabular}

*(HS): Highly Significant.

\section{Discussion}

Gastric cancer is ranking one of the most common malignant neoplasms. Gastric cancer is attributed to a high cancer-related mortality worldwide [12]. Most gastric cancer patients are often diagnosed with an advanced stage. Discovery of new diagnostic biomarkers for early detection of gastric cancer remains an urgent need [13]

It is well acknowledged that PARP 1, the most abundant member of the PARP superfamily, is a key DNA repair factor involved in base excision repair occurring in response to DNA damage [14] PARP1 is a highly conserved cell signaling protein that exclusively catalyzes poly ADP-ribosylation of DNA-binding proteins, such as BRCA1, thereby modulating their activity. Overexpression of PARP1 has been identified in different human cancers [15] However, few papers have studied PARP 1 expression in gastric adenocarcinoma.

The present study aims to detect PARP1 expression at mRNA level using qRT-PCR technique and protein level using immunohistochemistry in gastric adenocarcinoma tissue and compare its level in adjacent non-cancerous tissue. The correlation between PARP1 and HER2 status was also assessed in addition to its correlation with different clinicopathologic parameters.

The current study demonstrated that PARP1 detection at both mRNA level and protein expression was significantly higher in in gastric adenocarcinoma tissues than that in adjacent noncancerous tissue $(p<0.001)$. PARP1 protein was seen in $57.5 \%$ of study gastric adenocarcinoma cases. The level of expression of PARP1 mRNA expression level was significantly detected in $(62.5 \%)$ of gastric adenocarcinoma tissues ( $p$ $<0.001)$.

In addition, the present work revealed that overexpression of PARP1 was correlated with depth of invasion $(p<0.001)$, advanced tumor stage $(p$ $<0.001)$, nodal metastasis $(p<0.05)$ and distant metastasis status $(p<0.001)$ but not correlated with patient age, gender, tumor type or grade of differ- entiation. Consequently, our results might provide further evidence of PARP1 being a potential biomarker of carcinogenesis, aggressiveness and poor prognosis in gastric adenocarcinoma.

Previous reports have revealed similar results. The study of Park et al., [16] demonstrated that PARP1 proteins was observed in $54 \%$ of gastric carcinoma and was correlated with tumor invasion $(p<0.001)$, higher tumor stage $(p<0.001$, lymph node metastasis $(p<0.001)$, and venous invasion $(p=0.017)$ and more shorter OS $(p<0.001)$. The study of Liu et al., [17] showed that increased PARP-1 expression was associated with lymph node metastasis, advanced TNM stage and reduced DFS and OS in gastric cancer patients.

The recent study of Afzal et al., [10] detected significant up-regulation of PARP 1 in gastric carcinoma $(p<0.001)$ and significant correlation with poor prognostic factors as T stage $(p<0.01)$ and lymph node metastasis and poor survival. Moreover, they found that upregulation of PARP 1 was significantly higher in $\mathrm{H}$. pylori positive gastric cancer (HPGC) cases and they explained that $\mathrm{H}$. pylori is associated by an increased oxygen free radical formation with increased oxidative stress and chronic accumulation of DNA damage.

The study of Wang et al., [18] that increased PARP1 activity in gastric carcinoma cells is responsible for cisplatin resistance and that PARP1 inhibitor can significantly enhance cisplatin induced DNA damage and apoptosis, indicating potential clinical significance of PARP1 activity in gastric carcinoma.

Association of PARP1 with poor prognostic factors had been documented in other types of cancers as breast cancer [19], hepatocellular carcinoma [20], cancer ovary [21] and melanoma [22].

The role of PARP1 in carcinogenesis and cancer progression may be clarified by its dual functions in both DNA repair and transcriptional regulation. PARP1 can modulate the transcription of many oncogenes, as hypoxia-inducible factor $1 \alpha$ and $2 \mathrm{~A}$ genes and Vascular Endothelial Growth Factor Receptor 1 (VEGFR1) gene [23]. PARP1 regulates gene expression through different mechanisms as chromatin remodeling, DNA methylation pathways and RNA polymerase II [24]

The study of $\mathrm{Pu}$ et al., [25] demonstrated that PARP-1 has a role in regulation of Epithelialmesenchymal Transition (EMT) in prostate cancer. Moreover, the study of Choi et al., [26] revealed that PARP1 upregulates metastasis of lung cancers 
by improving PARP1-mediated transcription of S $1000 A 4$ and CLDN7.

Concerning the correlation between PARP1 and HER2 status, the present study demonstrated positive significant correlation between PARP1 positive expressions and positive HER2 status in gastric carcinoma cases. To our best knowledge, this may be the first study identifying significant correlation between PARP1 and HER2 in gastric carcinoma. This allows us to think about the possibility of combining PARP1 inhibitor therapeutics with anti HER2 therapeutics for gastric carcinoma patients to obtain optimal benefits of chemotherapy.

In consistence with the present results, the study of Stanley et al., [9] revealed a statistically significant increase in PARP1 protein levels in HER2+ breast cancers. The study of Wielgos et al., [27] clarified that increased PARP1 expression in HER2+ breast cancers is regulated by the let-7a miRNA and that Ectopic expression of the let-7a anti-miRNA resulted in increased PARP1 protein.

On brief, our study provided additional evidence about the potential prognostic role of PARP1in gastric adenocarcinoma and highlighted important information about the link between PARP1 and HER2 pathways during the progression of gastric adenocarcinoma.

\section{Conclusion:}

PARP1 may have a potential role in carcinogenesis, and aggressiveness of gastric adenocarcinoma. A significant correlation between PARP1 and HER2 may highlight the role of PARP1in regulation of HER2 in gastric adenocarcinoma. Further research is needed to confirm the role of PARP1-HER2 axis in the progression of gastric carcinoma and possibility of a combined anti PARP 1 and anti HER2 chemotherapy strategy.

\section{Conflict of interest:}

No conflict of interest.

\section{References}

1- SITARZ R., SKIERUCHA M., MIELKO J., OFFERHAUS G.J.A., MACIEJEWSKI R. and POLKOWSKI W.P.: Gastric cancer: Epidemiology, prevention, classification, and treatment. Cancer Manag. Res., 10: 239-48. Published 2018 Feb. 7. doi: 10.2147/CMAR.S149619, 2018.

2- XIN Q., ZHANG N., YU H.B., et al.: CXCR7/CXCL12 axis is involved in lymph node and liver metastasis of gastric carcinoma. World J. Gastroenterol., 23 (17): 305365. doi: 10.3748/wjg.v23.i17.3053, 2017.

3- GUPTE R., LIU Z. and KRAUS W.L.: PARPs and ADPribosylation: Recent advances linking molecular functions to biological outcomes. Genes. Dev., 31 (2): 101-26. doi: 10.1101/gad.291518.116, 2017.
4- GHOSH R., ROY S. and FRANCO S.: PARP1 depletion induces RIG-I-dependent signaling in human cancer cells. PLoS One, 13 (3): e0194611. Published 2018 Mar. 28. doi: 10.1371/journal.pone.0194611, 2018.

5- RAY CHAUDHURI A. and NUSSENZWEIG A.: The multifaceted roles of PARP 1 in DNA repair and chromatin remodelling. Nat. Rev. Mol. Cell. Biol., 18 (10): 610-21, 2017.

6- BECK C., ROBERT I., REINA-SAN-MARTIN B., SCHREIBER V. and DANTZER F.: Poly (ADP-ribose) polymerases in double-strand break repair: Focus on PARP1, PARP2 and PARP3. Exp. Cell Res., 329: 18-25. doi: 10.1016/j.yexcr.2014.07.003, 2014.

7- GONÇALVES A., SABATIER R., CHARAFEJAUFFRET E., GILABERT M., PROVANSAL M., TARPIN C., EXTRA J.M., VIENS P. and BERTUCCI F.: Triple-negative breast cancer: Histoclinical and molecular features, therapeutic management and perspective. B. Cancer, 100: 453-64, 2013.

8- SALEMI M., GALIA A., FRAGGETTA F., CORTE C.L., PEPE P., VIGNERA S.L., IMPROTA G., BOSCO P. and CALOGERO A.E.: Poly (ADP-ribose) Polymerase 1 protein expression in normal and neoplastic prostatic tissue. Eur. J. Histochem., 57: 80-2, 2013.

9- STANLEY J., KLEPCZYK L., KEENE K., et al.: PARP1 and phospho-p65 protein expression is increased in human HER2-positive breast cancers. Breast Cancer Res. Treat., 150 (3): 569-79. doi:10.1007/s10549-015-3359-6, 2015.

10- AFZAL H., YOUSAF S., RAHMAN F., AHMED M.W., AKRAM Z., AKHTAR KAYANI M. and MAHJABEEN I.: PARP 1: A potential biomarker for gastric cancer. Pathol. Res. Pract., Aug., 215 (8): 152472, 2019.

11- AMATO M., PERRONE G., RIGHI D., PELLEGRINI C., RABITTI C., Di MATTEO F., et al.: HER2 status in gastric cancer: Comparison between primary and distant metastatic disease. Pathol. Oncol. Res. POR, 23: 55-61. doi: 10.1007/s12253-016-0082-5, 2017.

12- YANG T.T., CAO N., ZHANG H.H., et al.: Helicobacter pylori infection-induced H3Ser10 phosphorylation in stepwise gastric carcinogenesis and its clinical implications. Helicobacter, 23 (3): e12486. doi: 10.1111/hel.12486, 2018.

13-MATSUOKA T. and YASHIRO M.: Biomarkers of gastric cancer: Current topics and future perspective. World J. Gastroenterol., 24 (26): 2818-32. doi:10.3748/wjg.v24.i26. 2818, 2018.

14- ZHEN Y. and YU Y.: Proteomic Analysis of the Downstream Signaling Network of PARP1. Biochemistry. 57 (4): 429-40. doi:10.1021/acs.biochem.7b01022, 2018.

15- GHOSH R., ROY S. and FRANCO S.: PARP1 depletion induces RIG-I-dependent signaling in human cancer cells. PLoS One, 13 (3): e0194611. Published 2018 Mar. 28. doi: 10.1371/journal.pone.0194611, 2018.

16- PARK S.H., JANG K.Y., KIM M.J., et al.: Tumor suppressive effect of PARP1 and FOXO3A in gastric cancers and its clinical implications. Oncotarget, 6 (42): 4481944831. doi: 10. 1 8632/oncotarget.6264 2015.

17- LIU Y., ZHANG Y., ZHAO Y., GAO D., XING J. and LIU H.: High PARP-1 expression is associated with tumor 
invasion and poor prognosis in gastric cancer. Oncol. Lett., 12 (5): 3825-35. doi:10.3892/ ol.2016.5169, 2016.

18- WANG Q., XIONG J., QIU D., ZHAO X., YAN D., XU W. and ZHOU J.: Inhibition of PARP1 activity enhances chemotherapeutic efficiency in cisplatin-resistant gastric cancer cells. The International Journal of Biochemistry \& Cell Biology, 92: 164-72. doi: 10. 10 16/j.biocel.2017. 08.001, 2017.

19- MAZZOTTA A., PARTIPILO G., De SUMMA S., GIOTTA F., SIMONE G. and MANGIA A.: Nuclear PARP1 expression and its prognostic significance in breast cancer patients. Tumor Biol., 37: 6143-53, 2016.

20- LI J., DOU D., LI P., LUO W., LV W., ZHANG C., SONG X., YANG Y., ZHANG Y., XU Y., XIAO F., WEI Y., QIN J., LI H. and YANG X.: PARP-1 serves as a novel molecular marker for hepatocellular carcinoma in a Southern Chinese Zhuang population.Tumour Biol., Jul., 39 (7): $1010428317706914,2017$.

21- BI F.F., LI D. and YANG Q.: Promoter hypomethylation, especially around the E26 transformation-specific motif, and increased expression of poly (ADP-ribose) polymerase 1 in BRCA-mutated serous ovarian cancer. BMC Cancer, 13: 90. Published 2013 Feb. 26. doi: 10.1186/1471-240713-90, 2013.

22- RODRÍGUEZ M.I., PERALTA-LEAL A., O'VALLE F., et al.: PARP-1 regulates metastatic melanoma through modulation of vimentin-induced malignant transformation. PLoS Genet., 9 (6): e1003531. doi:10.1371/journal.pgen. 1003531, 2013.

23- WANG L., LIANG C., LI F., et al.: PARP1 in Carcinomas and PARP1 Inhibitors as Antineoplastic Drugs. Int. J. Mol. Sci., 18 (10): 2111. Published 2017 Oct. 8. doi: 10.3390/ijms18102111, 2017.

24- FENG F.Y., De BONO J.S., RUBIN M.A. and KNUDSEN K.E.: Chromatin to Clinic: The Molecular Rationale for PARP1 Inhibitor Function. Mol. Cell, 58: 925-34, 2015.

25- PU H., HORBINSKI C., HENSLEY P.J., MATUSZAK E.A., ATKINSON T. and KYPRIANOU N.: PARP-1 regulates epithelial-mesenchymal transition (EMT) in prostate tumorigenesis. Carcinogenesis, 35 (11): 2592 601. doi:10.1093/carcin/bgu183, 2014.

26- CHOI E.B., YANG A.Y., KIM S.C., LEE J., CHOI J.K., CHOI C. and KIM M.Y.: PARP1 enhances lung adenocarcinoma metastasis by novel mechanisms independent of DNA repair. Oncogene, 35: 4569-79, 2016.

27- WIELGOS M.E., RAJBHANDARI R., COOPER T.S., WEI S., NOZELL S. and YANG E.S.: Let-7 Status Is Crucial for PARP1 Expression in HER2-Overexpressing Breast Tumors. Mol. Cancer Res., 15 (3): 340-7. doi: 10.1158/1541-7786.MCR-16-0287-T, 2017.

\section{آهمية ظهور الدلالة (PARP-1) فى سرطان المعدة بإستخدام الكيمياء المناعية وتحليل البوليميراز المتسلسل اللحظى المرسال وعلاقته بالدلالة (HER2)}

المقدمة: يعد سرطان المعدة واحداً من آكثر الآدرام السرطانية شيوعاً وغالباً ما يتم تشخيص معظم مرضى سرطان المعدة بمرحله متقدمة

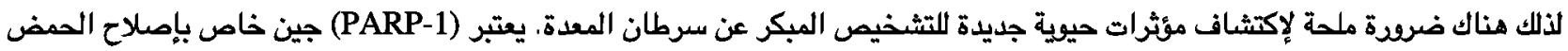

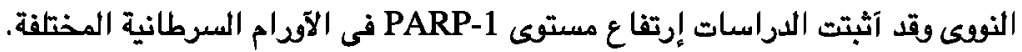

الهدف من البحث: دراسة ظهور PARP-1 بإستخدام الكيمياء المناعية وتحليل البوليميراز المتسلسل اللحظى وتوضيع دورة في نشآة وتطور سرطان المعدة الغدى وعلاقته بالدلالة HER2.

طريقة البحث: تم تقييم التعبير الكمى لبرتينات HER2, PARP-1 بواسطة الكيمياء المناعية وتم آيضاً تقييم الحمض النوصى الريبونى

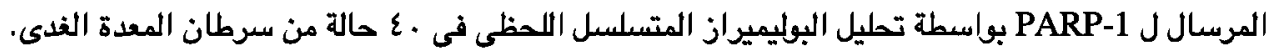

النتائج: آظهرت هذه الدراسة آن برتين PARP-1 يتواجد بنسبة (0V.0\%) في سرطان المعدة الغدى آما الحمض النوفى الريبوذى المرسال

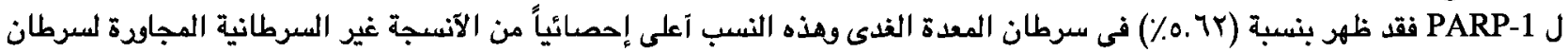

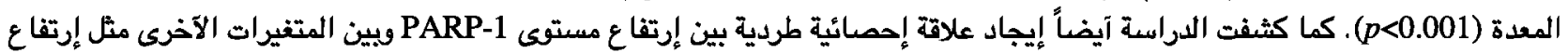

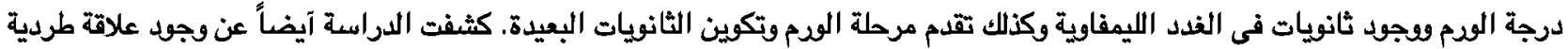

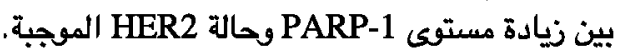

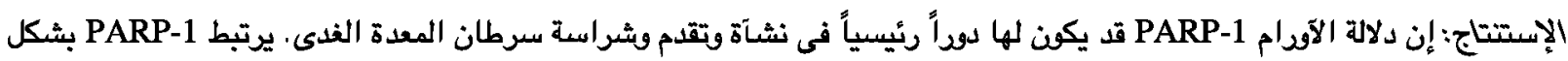

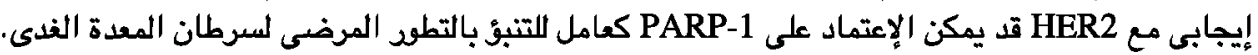

